\title{
Variability in leaf rust susceptibility among peach cultivars
}

\author{
Idemir Citadin ${ }^{1}$, Sérgio Miguel Mazaro², Moeses Andrigo Danner ${ }^{3}$, Maria do Carmo Bassols Raseira ${ }^{4}$, \\ Gustavo Malagi ${ }^{5}$
}

\begin{abstract}
The aim of this work was to estimate the susceptibility of thirty-six peach cultivars to leaf rust caused by Tranzschelia discolor f. sp. persica. The incidence and severity of the disease as well as defoliation in peach trees of an experimental orchard of Parana Federal University of Technology, Campus Dois Vizinhos were evaluated on the growing seasons 2004/2005 and 2005/2006. Immunity to this disease was not observed in the studied cultivars. There was difference in leaf rust intensity depending on the growing season conditions. Cultivars 'Pilcha', 'Sinuelo', 'Chirua', 'Sulina', 'Eldorado' and 'Pampeano' showed tolerance to leaf rust, whereas cultivars 'Vila Nova', 'Fla 1372', 'Coral 2', 'Chimarrita', 'Della Nona', 'BR-1' and 'Guaiaca' showed high susceptibility.
\end{abstract}

Key words: Prunus persica L. Batsch, disease resistance, dissimilarity measures.

\section{RESUMO}

\section{Variabilidade entre cultivares de pessegueiro quanto a suscetibilidade à ferrugem da folha (Tranzschelia discolor f. sp. persica)}

Este trabalho objetivou avaliar a suscetibilidade de trinta e seis cultivares de pessegueiro à ferrugem da folha. Foram realizadas avaliações de percentual de incidência e severidade da doença nas folhas e percentual de desfolha, durante os ciclos de 2004/2005, e 2005/2006, em uma coleção da Universidade Tecnológica Federal do Paraná, Campus Dois Vizinhos. Não foi observada imunidade à ferrugem da folha nos cultivares avaliados. Houve diferença na intensidade da doença em função das condições climáticas de cada ciclo. Os cultivares 'Pilcha', 'Sinuelo’, 'Chirua', 'Sulina', 'Eldorado’ ' 'Pampeano’ se mostraram tolerantes à ferrugem, enquanto que ‘Vila Nova’, 'Fla 1372’ (Maravilha), 'Coral 2', 'Chimarrita', ‘Della Nona’, ‘BR-1’ e ‘Guaiaca’ foram classificadas como altamente suscetíveis.

Palavras-chave: Prunus persica (L.) Batsch, resistência a doenças, medidas de dissimilaridade.

Recebido para publicação em novembro de 2008 e aprovado em fevereiro de 2010

${ }^{1}$ Engenheiro-Agrônomo, Doutor. Universidade Tecnológica Federal do Paraná, Campus Pato Branco, Via do Conhecimento, Km 01, Caixa Postal 571, 85501-970, Pato Branco, PR, Brasil. idemir@utfpr.edu.br.

${ }^{2}$ Engenheiro-Agrônomo, Doutor. Universidade Tecnológica Federal do Paraná, Campus Dois Vizinhos, Estrada para Boa Esperança, Km 04, 85660-00, Dois Vizinhos, PR, Brasil. sergio@utfpr.edu.br.

${ }^{3,5}$ Engenheiros-Agrônomos, Mestres. Estudantes do Programa de Pós-Graduação em Agronomia, Universidade Tecnológica Federal do Paraná, Campus Pato Branco, Via do Conhecimento, Km 01, Caixa Postal 571, 85501-970, Pato Branco, PR, Brasil. moesesandrigo@yahoo.com.br, malagi@agronomo.eng.br.

${ }^{2}$ Engenheira-Agrônoma, Ph. Doctor. Embrapa Clima Temperado, BR 392, Km 78, Caixa postal 403, 96001-970, Pelotas, RS, Brasil, bassols@cpact.embrapa.br. 


\section{INTRODUCTION}

Peach rust caused by Tranzschelia discolor (Fuckel) Tranzschel \& Litv. is an economically important disease in several peach production areas around the world (Burnett 1968, Bolkan et al., 1985, Bertrand 1995). In Brazil, the incidence of disease is higher in areas with high temperatures and humidity, mainly below the parallel 25ÚS, in Paraná and São Paulo states.

This fungus affects mainly leaves, in the post-harvest period, producing angular and chlorotic lesions, on the upper surface, and with rusty orange-brown pustules or uredinia on the lower leaf surface. Heavy leaf infection can result in premature defoliation of the tree which may stimulate flowering during the fall or early winter and reduce tree vigor or yield in the next season (Bertrand 1995, Martins \& Amorim 2000, Centellas-Quezada 2000, Soto-Estrada \& Adaskaveg 2004, Garrido \& Sonego 2005, Citadin et al., 2005). According to Amorim (1996), depending on defoliation intensity, the yield losses can reach $30 \%$.

The pathogen can survive during the winter in other hosts, but this is not essential to complete its cycle under hot climates (Anderson 1956). The primary infection in leaves occurs during the late spring, through germination of urediniospores (structure of resistance of the fungus) overwintered in stem lesions (Goldsworthy \& Smith 1931, Soto-Estrada \& Adaskaveg 2004). Depending on the weather in spring and summer, leaves can be infected throughout the growing season. Urediniospores germinate over a wide temperature range: 8-38ÚC; however, $13-26{ }^{\circ} \mathrm{C}$ is the optimum. A wet period of near $18 \mathrm{~h}$ at 20ÚC, frequent in southern Brazil spring/summer, is ideal for heavy leaf infections. The incubation period in leaves is around 7 to 10 days. The urediniospores are spread by dry winds. Spread is also favored by rain water or irrigation (Bertrand 1995). Fruit infections are not common in Brazil.

The peach rust severity changes depending on the site, the year, the climatic conditions, and the host (Centellas-Quezada 2000, Soto-Estrada \& Adaskaveg 2004). Peach genotypes show differences in the level of rust tolerance detected by the leaf retention in later summer, the incidence level and disease progression curve on leaf severity during the growing season (Barbosa et al., 1994, Centellas-Quezada 2000, Citadin et al., 2005). The cultivar Cristal Taquari, a genotype released by 'Embrapa Clima Temperado', is immune of rust leaf (Centellas-Quezada 2000). Barbosa et al. (1994) evaluated 18 peach and six nectarine cultivars released by the Instituto Agronomico de Campinas (IAC, Brazil). All these cultivars are susceptible to rust, however they showed great differences in susceptibility levels. Citadin et al. (2005) observed differences in leaf rust susceptibility among three cultivars ('Chimarrita', 'Premier’ and 'Ouro'). 'Ouro' was found the most susceptible of them. These findings indicate that peach breeding programs can improve new cultivars with higher level of resistance to Tranzschelia discolor.

Chemical treatment is the most used control measure, however there are few registered fungicides for the control of leaf rust in Brazil, which increases the risk of developing resistant biotypes. In addition, fungicides not always provide a satisfactory control of this disease (Carvalho et al., 2002). Winter treatments with Bordeaux and Sulfocalcic mixture can reduce the initial inoculum of the fungus. This technique associated with sulphur applications during the growing season and the cultivation of resistant or tolerant cultivars are more economic and environmentally desirable control methods for peach rust.

Identification of resistant or tolerant germoplasm to peach rust can reduce production costs and could be used in breeding programs to obtain new cultivars more resistant or tolerant to this serious disease.

The aim of this work was to estimate the susceptibility of thirty-six peach cultivars to leaf rust caused by Tranzschelia discolor.

\section{MATERIAL AND METHODS}

The work was conducted in a peach orchard of the Parana Federal University of Technology - Campus Dois Vizinhos (25Ú 44' S, 53Ú 4' W and 520 m altitude). The plants used in the experiment were seven years old at the beginning of the study. The local climate is subtropical humid (Cfa - Koppen classification), without dry season, with hot summers (average temperature of $22{ }^{\circ} \mathrm{C}$ ), few occurrences of frosts in the winter (average temperature below $18{ }^{\circ} \mathrm{C}$ ), and frequent rains, always above $60 \mathrm{~mm}$ a month. The annual rainfall varies from 1800 to $2000 \mathrm{~mm}$ (Table 1).

Observations on defoliation and rust incidence and severity on remained leaves were recorded during the growing season in 2004/2005 (12/20/2004); and 2005/2006 (12/19/2005 and 02/16/2006). The experiment was arranged in a randomized blocks design with four replications, with one plant per plot. Four one-year-old stems (approximately $30 \mathrm{~cm}$ long) were collected from each untreated tree. Defoliation was determined for each sampling date and was expressed as percentage. The remaining leaves on each one-year-old stem with one or more uredinia were considered diseased. Disease incidence was expressed as percentage of the number of infected leaves in relation to total number of sampled leaves. Severity was expressed as a percentage of the leaf area occupied by bright yellow spots. 
Table 1. Monthly total precipitation (mm) from November to February in Dois Vizinhos - PR, during the growing season in 2004/ 2005 and 2005/2006

\begin{tabular}{lcccc}
\hline \multirow{2}{*}{ Growing season } & \multicolumn{4}{c}{ Precipitation (mm) } \\
\cline { 2 - 5 } & November & December & January & February \\
\hline $2004 / 2005$ & 180 & 121 & 254 & 59 \\
$2005 / 2006$ & 113 & 71 & 294 & 118,8 \\
Historical averages & 147 & 178 & 225 & 176 \\
\hline
\end{tabular}

Thirty six cultivars were evaluated: FlordaPrince, Coral, Coral tardio, Esmeralda, Maciel, Chinoca, Chiripá, Della Nona, Sulina, Pala, Precocinho, BR-1, Riograndense, Peach, Vila Nova, Chimarrita, Coral 2, Fla 1372 (Maravilha), Guaiaca, Vanguarda, Planalto, Marli, Pilcha, Premier, BR3, Sinuelo, Eldorado, Jade, Granada, Pampeano, Chula, Cardeal, Chirua, Princesa, São Pedro, and Douradão.

The cultivars were classified as tolerant, moderately susceptible, susceptible and highly susceptible, according to the classification proposed in this study (Table 2). Correlation analyses were accomplished by the Pearson's model, using the Genes software (Cruz, 2001).

Analysis of variance was performed for severity and defoliation (2004/2005 and 2005/2006 growing seasons) and incidence (2005/2006 growing season). Means of variables were grouped by the Scott-Knott test ( $P d$ '0.05) (Scott \& Knott, 1974). The distances among all genotype pairs were estimated using the generalized distance of Mahalanobis $\left(\mathrm{D}^{2}\right)$ based on standardized means for all measured traits. A dendrogram was obtained using the UPGMA(Unweighted Pair Group Method with Arithmetic Average) clustering method (Johnson \& Wichern, 1998). The relative importance of evaluated traits concerning genetic dissimilarity was obtained by means of the contribution of $\mathrm{D}^{2}$ components, relative to each trait, to the total observed dissimilarity (Singh 1981). An analysis of canonical variables was also performed in order to obtain the genotype dispersion plot, using the Genes software (Cruz, 2006).

\section{RESULTS AND DISCUSSION}

We chose not to use the arbitrary scale proposed by Martins (1994), because the severity levels observed were usually higher than that described by this author and did not allow classifying cultivars according to susceptibility levels.

There were differences among genotype means when compared by the Scott-knott test (Tables 3 and 4), except for rust incidence (Table 5). Grouping of genotypes by the Scott-Knott test differed from the groups formed by the classification proposed in Table 2. This difference might be related to the hight coefficient of variation observed for severity, defoliation, and incidence (Table 3, 4 and 5).

The average of peach leaf rust severity on Dec. 20, 2004 and Dec. 12, 2005 was 24.3\%, and 3.5\%, respectively. In the second evaluation in the $2005 / 2006$ growing season (02/16/2006), the average of severity raised to $17.6 \%$ (Table $3)$. The average defoliation caused by peach leaf rust, in these growing seasons, was 41.2 and 31.6, respectively (Table 4). In 2004/2005 growing season, when disease increased early in the season, total precipitation ranged from $180 \mathrm{~mm}$ in November to $121 \mathrm{~mm}$ in December. In the 2005/2006 growing season, when mid-season epidemics occurred, total precipitation ranged from 113 to $71 \mathrm{~mm}$ from November to December, which is below the historical average (Table 1). Soto-Estrada \& Adaskaveg (2004) reported differences in peach leaf rust epidemics in function of the climatic conditions of the growing seasons.

During the 2004 growing season, disease increased earlier. Diseased leaf incidence was 100\% on Dec. 20, 2004, for all genotypes (data not shown). But, no difference was detected by the Scott-Knott test from the first evaluation of the 2005/2006 growing season (12/19/2005) when the average incidence was $37.2 \%$, (Table 5). Rust defoliation was not observed either. On the second evaluation (02/16/2006), the average incidence increased up to $100 \%$ (data not shown).

Table 2. Parameters of classification of peach cultivars according to the manifestation of peach leaf rust (Tranzschelia discolor)

\begin{tabular}{lccc}
\hline Classification & *Incidence (\%) & **Severity (\%) & Defoliation (\%) \\
\hline Tolerant & $<15$ & $<10$ & $<20$ \\
Moderately susceptible & $15.1-30$ & $10.1-20$ & $20.1-30$ \\
Susceptible & $30.1-60$ & $20.1-30$ & $30.1-50$ \\
Highly susceptible & $>60.1$ & $>30.1$ & $>50.1$ \\
\hline
\end{tabular}

* Percentage of leaves with one or more urediniospores.

** Percentage of the peach leaf area with symptoms of the disease. 
Large differences in disease severity and defoliation were found among cultivars (Table 3 and 4). However, none of the cultivars was immune to rust.

According to the adopted criteria of classification (Table 2), cultivars ‘Sulina', 'Chirua', and 'Pampeano' were considered tolerant for severity (Table 3) and defoliation (Table 4). 'Chirua' and 'Pampeano’ were also tolerant by the incidence criteria (Table 5). The cultivars 'Chimarrita', 'Vila Nova', 'Fla 1372', 'BR-1' and ‘Coral 2' were classified as being highly susceptible, considering both severity and defoliation (Table 3 and 4). The cultivars 'Guaiaca' and 'Della Nona' were also classified as highly susceptible considering defoliation (Table 4). However by the disease severity criteria (Table 3) these cultivars were classified as susceptible. 'Riograndense' was classified as highly susceptible by the incidence (Table 5) and severity criteria (Table 3), however it was classified as susceptible by the defoliation criteria, with $47.2 \%$ of defoliation (Table 4 ).

Table 3. Peach cultivars classification as a function of leaf rust severity

\begin{tabular}{|c|c|c|c|c|}
\hline \multirow[b]{2}{*}{ CULTIVAR } & \multicolumn{3}{|c|}{ \% SEVERITY } & \multirow[b]{2}{*}{ CLASSIFICATION } \\
\hline & $\begin{array}{l}\text { 20/12/2004 - growing } \\
\text { season } 2004 / 05\end{array}$ & $\begin{array}{c}\text { 16/02/2006 - growing } \\
\text { season } 2005 / 06\end{array}$ & $\begin{array}{l}\text { Average of } \\
\text { years (\%) }\end{array}$ & \\
\hline Sulina & $5.9 \mathrm{a}^{*}$ & $12.50 \mathrm{a}$ & 9.20 & \\
\hline Chirua & $12.7 \mathrm{a}$ & $5.75 \mathrm{a}$ & 9.23 & Tolerant \\
\hline Pampeano & 9.2 a & 9.25 a & 9.23 & \\
\hline Eldorado & $16.3 \mathrm{a}$ & $5.00 \mathrm{a}$ & 10.65 & \\
\hline Chinoca & $12.1 \mathrm{a}$ & $11.75 \mathrm{a}$ & 11.90 & \\
\hline Chula & $13.4 \mathrm{a}$ & $11.67 \mathrm{a}$ & 12.51 & \\
\hline Coral Tardio & $17.6 \mathrm{a}$ & 7.58 a & 12.59 & \\
\hline Pala & $10.6 \mathrm{a}$ & 14.75 a & 12.65 & \\
\hline Sinuelo & $15.7 \mathrm{a}$ & 9.75 а & 12.73 & \\
\hline Pilcha & $20.1 \mathrm{a}$ & 9.92 а & 14.98 & \\
\hline Chiripá & $15.8 \mathrm{a}$ & 14.83 a & 15.29 & Moderately Susceptible \\
\hline Esmeralda & $15.7 \mathrm{a}$ & $15.25 \mathrm{a}$ & 15.48 & \\
\hline Princesa & $19.0 \mathrm{a}$ & $15.00 \mathrm{a}$ & 17.00 & \\
\hline Premier & $12.6 \mathrm{a}$ & $21.92 \mathrm{a}$ & 17.23 & \\
\hline Douradão & $19.1 \mathrm{a}$ & 15.50 a & 17.29 & \\
\hline Coral & $17.4 \mathrm{a}$ & 19.33 a & 18.34 & \\
\hline São Pedro & 19.9 a & $17.00 \mathrm{a}$ & 18.43 & \\
\hline Marli & $14.0 \mathrm{a}$ & 23.17 a & 18.56 & \\
\hline Maciel & 23.3 a & 17.17 a & 20.23 & \\
\hline Vanguarda & $18.0 \mathrm{a}$ & 22.75 a & 20.38 & \\
\hline Della nona & $21.8 \mathrm{a}$ & 20.17 a & 20.98 & \\
\hline Jade & $36.4 \mathrm{c}$ & $7.00 \mathrm{a}$ & 21.70 & \\
\hline FlordaPrince & $28.1 \mathrm{~b}$ & 19.08 a & 23.59 & \\
\hline Cardeal & $24.8 \mathrm{~b}$ & $22.92 \mathrm{a}$ & 23.83 & Susceptible \\
\hline Precocinho & $30.4 \mathrm{~b}$ & 18.42 a & 24.38 & \\
\hline Planalto & $35.0 \mathrm{~b}$ & 15.67 a & 25.33 & \\
\hline Peach & $32.8 \mathrm{~b}$ & $22.08 \mathrm{a}$ & 27.42 & \\
\hline BR 3 & $37.3 \mathrm{~b}$ & $19.42 \mathrm{a}$ & 28.33 & \\
\hline Granada & $35.3 \mathrm{~b}$ & 21.92 a & 28.58 & \\
\hline Guaica & $38.7 \mathrm{c}$ & 19.42 a & 29.06 & \\
\hline Coral 2 & $39.3 \mathrm{c}$ & $21.42 \mathrm{a}$ & 30.36 & \\
\hline BR 1 & $24.5 \mathrm{~b}$ & 38.25 a & 31.38 & \\
\hline Rio Grandense & $39.4 \mathrm{c}$ & 25.92 a & 32.63 & \\
\hline Fla 1372 & $46.7 \mathrm{c}$ & $25.00 \mathrm{a}$ & 35.85 & Highly Susceptible \\
\hline Vila nova & 59.5 c & 12.33 a & 35.92 & \\
\hline Chimarrita & $36.8 \mathrm{~b}$ & $45.00 \mathrm{a}$ & 40.88 & \\
\hline Average of cultivars (\%) & 24.3 & 17.6 & & \\
\hline C.V (\%) & 26.0 & 36.0 & & \\
\hline
\end{tabular}

*Means followed by the same letter in the column do not differ by the Scott-knott test $(P<0,05)$.

Rev. Ceres, Viçosa, v. 57, n.2, p. 185-193, mar/abr, 2010 
The cultivars 'FlordaPrince', 'Peach', and 'Cardeal' were classified as susceptible by the severity (Table 3) and defoliation criteria (Table 4), and highly susceptible by incidence criteria (Table 5).

The cultivars with the lowest defoliation ( $<20 \%)$ were 'Pilcha', 'Sinuelo', 'Chirua', 'Sulina', 'Eldorado’, 'Pampeano', and 'Chula', considered as leaf rust tolerant. These cultivars can be used as parents in breeding program aiming improve rust tolerance. Nevertheless, the cultivars
'Vila nova', 'Fla 1372', 'Coral’, ‘Chimarrita', 'Della Nona', 'BR-1', and 'Guaiaca' were classified as highly susceptible, with defoliation levels above $50.1 \%$, 'Vila nova' showed 92\% of defoliation (Table 4). These cultivars should not be used as parents in breeding crosses, in areas where rust is a serious problem. Besides, their management is costly, because they require more fungicide sprays to control rust. However, among the highly susceptible peach cultivars to leaf rust, there are some with good fruit quality,

Table 4. Peach cultivar classification as a function of defoliation caused by leaf rust

\begin{tabular}{|c|c|c|c|c|}
\hline \multirow[b]{2}{*}{ CULTIVAR } & \multicolumn{3}{|c|}{ \% DEFOLIATION } & \multirow[b]{2}{*}{ CLASSIFICATION } \\
\hline & $\begin{array}{l}\text { 20/12/2004 - growing } \\
\text { season 2004/05 }\end{array}$ & $\begin{array}{c}\text { 16/02/2006 - growing } \\
\text { season } 2005 / 06\end{array}$ & $\begin{array}{l}\text { Average of } \\
\text { years (\%) }\end{array}$ & \\
\hline Pilcha & $16.2 \mathrm{a}^{*}$ & $6.7 \mathrm{a}$ & 11.4 & \\
\hline Sinuelo & 20.3 a & $2.5 \mathrm{a}$ & 11.4 & \\
\hline Chirua & $21.7 \mathrm{a}$ & $1.7 \mathrm{a}$ & 11.7 & \\
\hline Sulina & $12.2 \mathrm{a}$ & $13.1 \mathrm{a}$ & 12.7 & Tolerant \\
\hline Eldorado & 27.9 a & $2.1 \mathrm{a}$ & 15.0 & \\
\hline Pampeano & $19.2 \mathrm{a}$ & $12.1 \mathrm{a}$ & 15.6 & \\
\hline Chula & $20.1 \mathrm{a}$ & $18.3 \mathrm{~b}$ & 19.2 & \\
\hline Princesa & $30.7 \mathrm{a}$ & $10.0 \mathrm{a}$ & 20.4 & \\
\hline Douradão & $33.2 \mathrm{a}$ & 7.9 a & 20.6 & \\
\hline Coral Tardio & $33.7 \mathrm{a}$ & $10.4 \mathrm{a}$ & 22.1 & \\
\hline Chinoca & $23.0 \mathrm{a}$ & $22.5 \mathrm{~b}$ & 22.7 & \\
\hline Maciel & $42.3 \mathrm{~b}$ & $5.4 \mathrm{a}$ & 23.9 & Moderately \\
\hline Premier & $31.7 \mathrm{a}$ & $17.5 \mathrm{~b}$ & 24.6 & susceptible \\
\hline Marli & $20.4 \mathrm{a}$ & $30.4 \mathrm{~b}$ & 25.4 & \\
\hline Esmeralda & 32.9 a & $18.3 \mathrm{~b}$ & 25.6 & \\
\hline Pala & $22.1 \mathrm{a}$ & $31.7 \mathrm{~b}$ & 26.9 & \\
\hline Vanguarda & $32.7 \mathrm{a}$ & $27.5 \mathrm{~b}$ & 30.1 & \\
\hline Chiripá & $33.1 \mathrm{a}$ & $30.7 \mathrm{~b}$ & 31.9 & \\
\hline Granada & $48.7 \mathrm{~b}$ & $21.3 \mathrm{~b}$ & 35.0 & \\
\hline Cardeal & 39.0 a & $39.6 \mathrm{c}$ & 39.3 & \\
\hline Jade & $66.1 \mathrm{c}$ & $12.9 \mathrm{a}$ & 39.5 & \\
\hline Coral & $45.8 \mathrm{~b}$ & $34.9 \mathrm{~b}$ & 40.4 & \\
\hline FlordaPrince & $53.2 \mathrm{~b}$ & $32.8 \mathrm{~b}$ & 43.0 & Susceptible \\
\hline Peach & $44.8 \mathrm{~b}$ & $42.4 \mathrm{c}$ & 43.6 & \\
\hline BR 3 & $58.3 \mathrm{~b}$ & $34.2 \mathrm{~b}$ & 46.2 & \\
\hline Rio Grandense & $49.8 \mathrm{~b}$ & $44.6 \mathrm{c}$ & 47.2 & \\
\hline Precocinho & $51.8 \mathrm{~b}$ & $43.9 \mathrm{c}$ & 47.8 & \\
\hline São Pedro & $41.4 \mathrm{~b}$ & $55.0 \mathrm{c}$ & 48.2 & \\
\hline Planalto & $64.5 \mathrm{c}$ & $32.3 \mathrm{~b}$ & 48.4 & \\
\hline Guaica & $62.0 \mathrm{c}$ & $45.3 \mathrm{c}$ & 53.6 & \\
\hline BR 1 & $43.0 \mathrm{~b}$ & $64.8 \mathrm{~d}$ & 53.9 & \\
\hline Della nona & $40.1 \mathrm{~b}$ & $71.6 \mathrm{~d}$ & 55.8 & \\
\hline Chimarrita & $71.1 \mathrm{c}$ & $58.8 \mathrm{~d}$ & 64.9 & Highly \\
\hline Coral 2 & $63.0 \mathrm{c}$ & $67.3 \mathrm{~d}$ & 65.2 & Susceptible \\
\hline Fla 1372 & $76.8 \mathrm{c}$ & $75.4 \mathrm{~d}$ & 76.1 & \\
\hline Vila nova & $92.1 \mathrm{c}$ & $92.1 \mathrm{~d}$ & 92.1 & \\
\hline Average of cultivars (\%) & 41.2 & 31.6 & & \\
\hline C.V (\%) & 33.6 & 39.4 & & \\
\hline
\end{tabular}

*Means followed by the same letters in the column do not differ by the Scott-knott test $(P<0.05)$. 
such as 'Chimarrita', one of the most planted in Southern Brazil. Centellas-Quezada (2000) suggested that 'Chimarrita' could be used in hybridizations with rust resistant or tolerant cultivars aiming to improve rust resistant and fruit quality in the progeny. Considering that inheritance of rust resistance seems to be a quantitative character, with addictive gene action, even if we cross cultivars with moderate susceptibility it is possible to obtain good resistance levels in some genotypes of the progeny (Centellas-Quezada, 2000).

Trees that are resistant or tolerant to Tranzschelia discolor can avoid, restrict or delay the development of the disease caused by this fungus. Each component or resistance mechanism (structural and biochemical) should be studied to determine their exact role in the defense system (Bell, 1981).

A highly significant correlation coefficient ( $r=0.99)$, i. e., the cultivars that show high percentage of incidence tend to show greater severity (Figure 1A). However, it has to be considered that in the first evaluation, the severity of the disease was low, no more than 3.5\%, even for the cultivars with $100 \%$ of incidence. Cultivars that have high incidence and low severity can be classified as tolerant, because the disease progress curve is slow. This may be caused by hypersensitivity reactions, as verified by Centellas-Quezada (2000). Structural and/or biochemical factors interfere in pathogen development (Pascholati \& Leite, 1997). The nutritional condition of the trees could also influence the

Table 5. Peach cultivars classification in function of incidence of leaf rust

\begin{tabular}{|c|c|c|}
\hline CULTIVAR & $\begin{array}{c}\text { \% INCIDENCE } \\
\text { 19/12/2005 - growing season } \\
2005 / 06\end{array}$ & CLASSIFICATION \\
\hline $\begin{array}{l}\text { Chirua } \\
\text { Coral Tardio } \\
\text { Chula } \\
\text { Sinuelo } \\
\text { Eldorado } \\
\text { Pilcha } \\
\text { Jade } \\
\text { Premier } \\
\text { Douradão } \\
\text { Pampeano } \\
\text { Planalto }\end{array}$ & $\begin{array}{l}1.6 \mathrm{a}^{*} \\
2.2 \mathrm{a} \\
2.3 \mathrm{a} \\
2.3 \mathrm{a} \\
2.5 \mathrm{a} \\
3.6 \mathrm{a} \\
5.1 \mathrm{a} \\
10.8 \mathrm{a} \\
12.3 \mathrm{a} \\
13.0 \mathrm{a} \\
14.6 \mathrm{a}\end{array}$ & 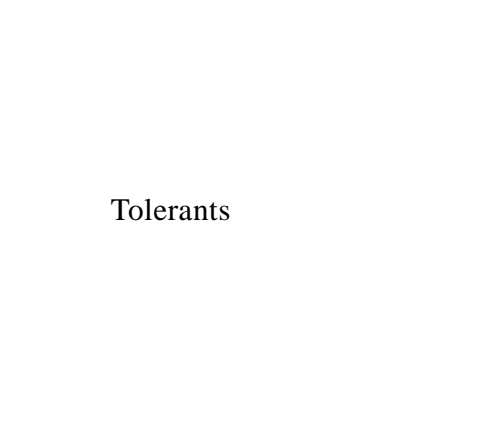 \\
\hline $\begin{array}{l}\text { BR 3 } \\
\text { Chinoca } \\
\text { Maciel } \\
\text { Marli } \\
\text { BR 1 } \\
\text { Chiripá }\end{array}$ & $\begin{array}{l}20.5 \mathrm{a} \\
20.5 \mathrm{a} \\
24.2 \mathrm{a} \\
24.4 \mathrm{a} \\
25.6 \mathrm{a} \\
28.4 \mathrm{a}\end{array}$ & Moderately susceptibles \\
\hline $\begin{array}{l}\text { Princesa } \\
\text { Granada } \\
\text { São Pedro } \\
\text { Coral } 2 \\
\text { Esmeralda } \\
\text { Pala } \\
\text { Coral } \\
\text { Precocinho } \\
\text { Vanguarda } \\
\text { Sulina } \\
\text { Chimarrita }\end{array}$ & $\begin{array}{l}32.3 \mathrm{a} \\
37.5 \mathrm{a} \\
43.4 \mathrm{a} \\
43.6 \mathrm{a} \\
43.8 \mathrm{~b} \\
45.0 \mathrm{~b} \\
48.1 \mathrm{~b} \\
48.5 \mathrm{~b} \\
51.2 \mathrm{~b} \\
55.4 \mathrm{~b} \\
55.6 \mathrm{~b}\end{array}$ & Susceptibles \\
\hline $\begin{array}{l}\text { Rio Grandense } \\
\text { Guaica } \\
\text { Cardeal } \\
\text { Della nona } \\
\text { Peach } \\
\text { Fla } 1372 \\
\text { Flor da Prince } \\
\text { Vila nova } \\
\text { CV }(\%)=44.0\end{array}$ & $\begin{array}{l}61.0 \mathrm{~b} \\
68.7 \mathrm{~b} \\
70.0 \mathrm{~b} \\
75.8 \mathrm{~b} \\
79.6 \mathrm{~b} \\
85.9 \mathrm{~b} \\
88.8 \mathrm{~b} \\
91.0 \mathrm{~b}\end{array}$ & Highly Susceptibles \\
\hline
\end{tabular}

*Means followed by the same letter in the column do not differ by the Scott-knott test $(P<0,05)$.

Rev. Ceres, Viçosa, v. 57, n.2, p. 185-193, mar/abr, 2010 
A

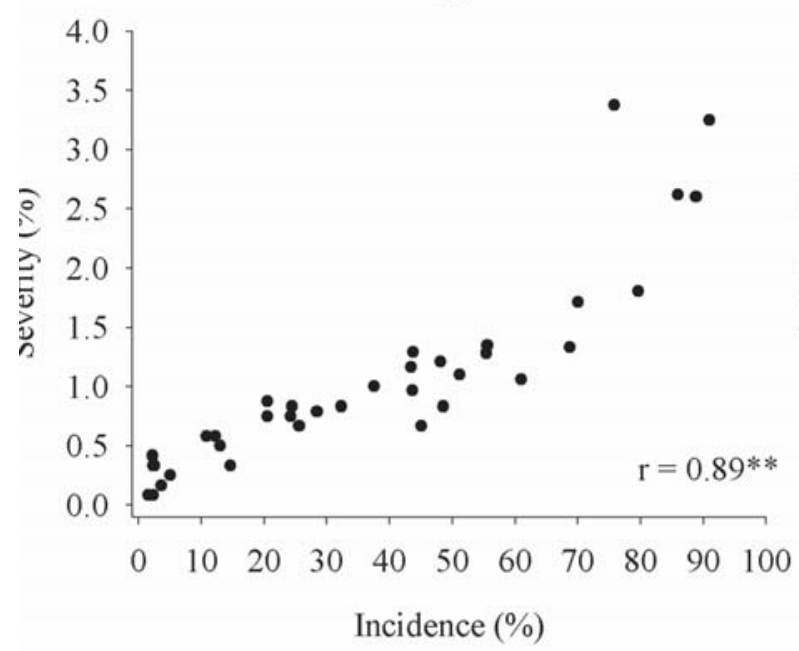

C

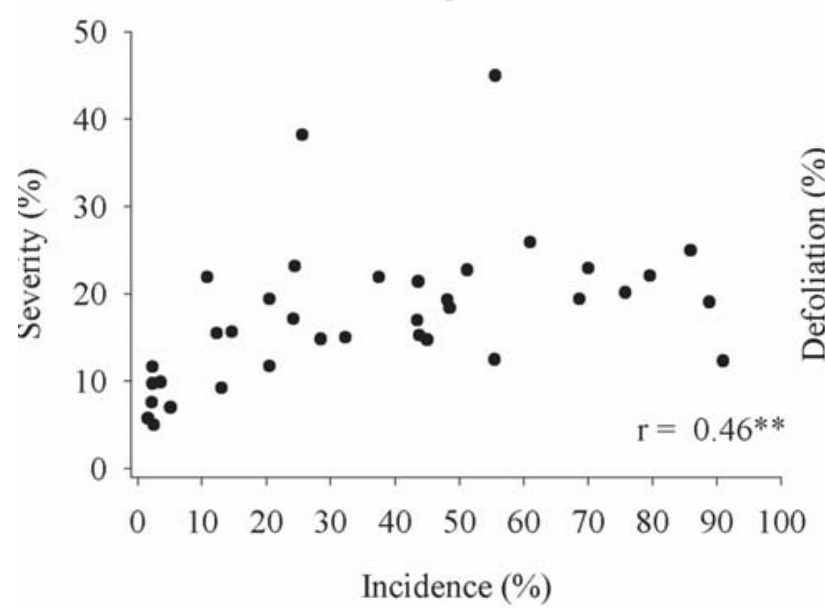

B

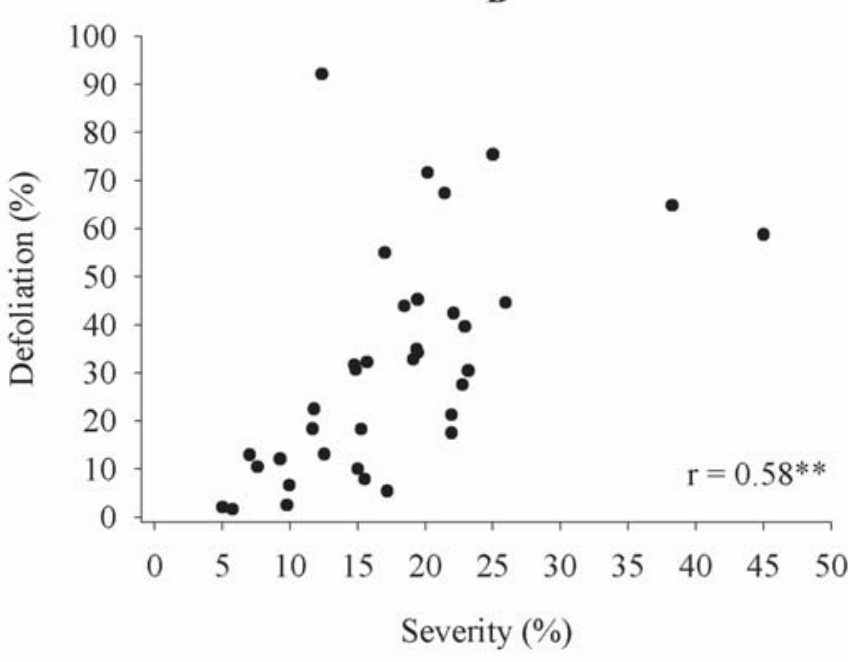

D

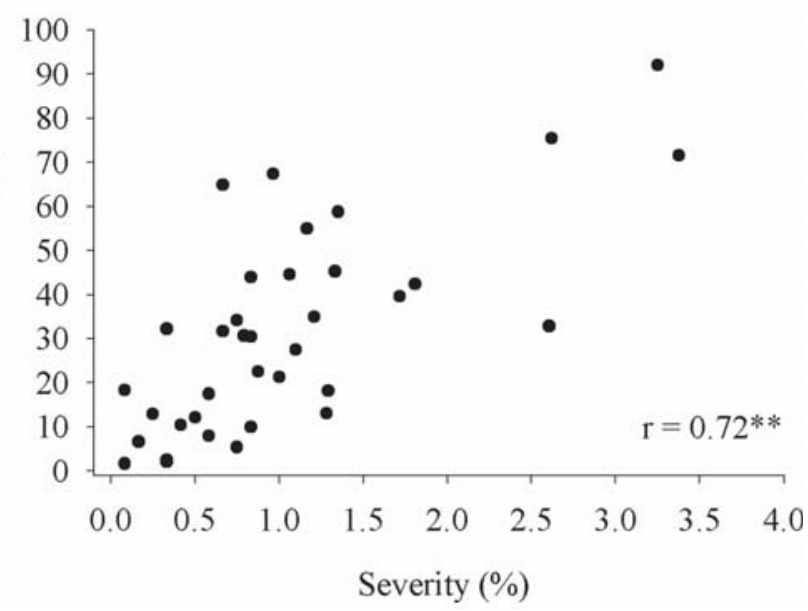

Figure 1. Correlation between incidence and severity on 19/12/2005 (A); severity and defoliation on 16/02/2006 (B); incidence on 19/ $12 / 2005$ and severity on 16/02/2006 (C); severity on 19/12/2005 and defoliation on 16/02/2006 (D).

resistance or susceptibility to pathogens. CentelhasQuezada (2000) observed significant negative correlation between the number of rust pustules in the peach leaf and its potassium content.

The correlation coefficient between percentage of defoliation and disease severity was highly significant $(r=0.58)$, i. e., the percentage of defoliation was directly related with disease severity. Severity levels up to $45 \%$ were observed (Figure 1B). This fact prevented the use of the diagrammatic scale proposed by Martins (1994). It is necessary to make a new diagrammatic scale for peach leaf rust, based on the real observations in the field, at this location.

Figure 1C shows the correlation between the incidence on $12 / 19 / 2005$ and the severity on $16 / 02 / 2006$. The correlation coefficient ( $\mathrm{r}=0.46)$ is highly significant, i. e., the cultivars that have higher incidence on 12/19/2005 tend to have higher severity on 02/16/2006. In Figure 1C, two points above the curve stand out, representing the performance of cvs. 'Chimarrita' and 'BR-1', with severity of $38.2 \%$ and $45 \%$, respectively, considered as highly susceptible to peach rust.

Figure 1D shows the correlation between severity on $12 / 19 / 2005$ and defoliation observed during the second evaluation (02/16/2006). The correlation coefficient ( $\mathrm{r}=0.72$ ) is highly significant, i. e., the cultivars with higher severity on $12 / 19 / 2006$ showed high defoliation on $02 / 16 / 206$, which was 60 days after the first evaluation.

Analysis of the graphic dispersal of canonical variable scores after the exclusion of redundant values (Figure 2) showed that genotypes 'Vila nova' (15) and 'Fla 13-72' (18) were the most distant, forming a distinct cluster, when compared with 'Chirua' (33), 'Pilcha' (23), and ‘Chula' (31). The first ones were highly susceptible whereas the others were resistant.

Analyzing the clusters formed by UPGMA with 50\% divergence (Figure 3), four groups were detected: the first composed by 'Vila nova', 'Guaiaca', and 'Fla 1372'; the second composed by 'Della nona'; the third composed by 'Br-1'and 'Chimarrita'; and the fourth composed by 


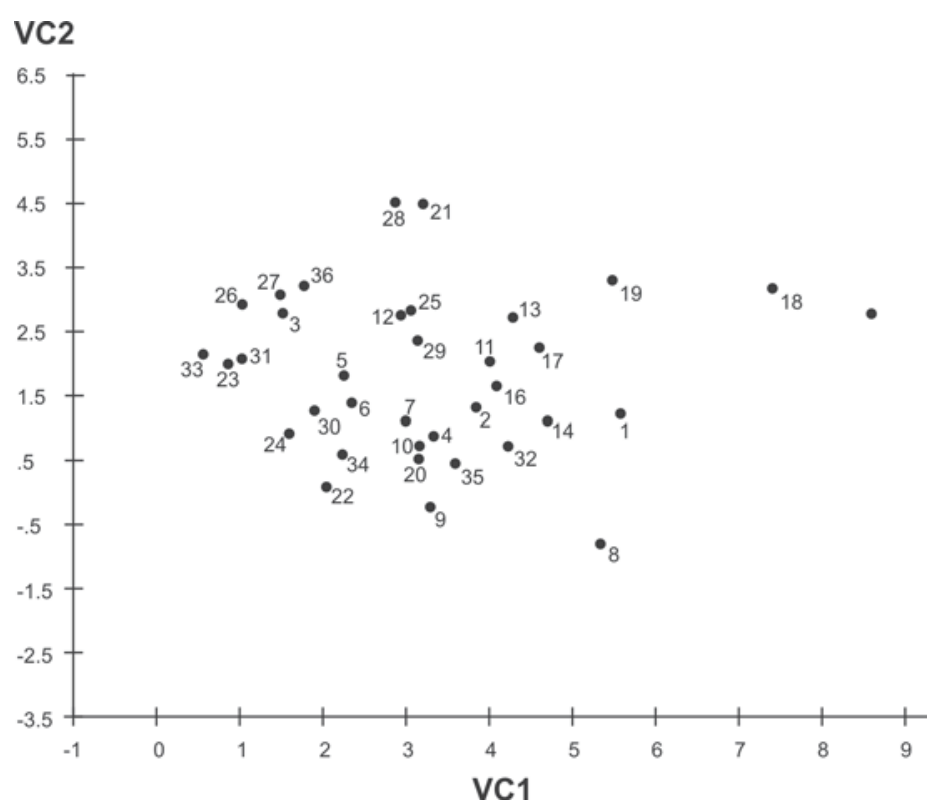

Figure 2. Dispersion biplot of 36 peach cultivar scores in relation to the first two canonical variables. FlordaPrince (1), Coral (2), Coral tardio (3), Esmeralda (4), Maciel (5), Chinoca (6), Chiripá (7), Della Nona (8), Sulina (9), Pala (10), Precocinho (11), BR-1 (12), Riograndense (13), Peach (14), Vila Nova (15), Chimarrita (16), Coral 2 (17), Fla 1372 (18), Guaiaca (19), Vanguarda (20), Planalto (21), Marli (22), Pilcha (23), Premier (24), BR-3 (25), Sinuelo (26), Eldorado (27), Jade (28), Granada (29), Pampeano (30), Chula (31), Cardeal (32), Chirua (33), Princesa (34), São Pedro (35), and Douradão (36).

Método de agrupamento: Ligação Média Entre Grupo (UPGMA)

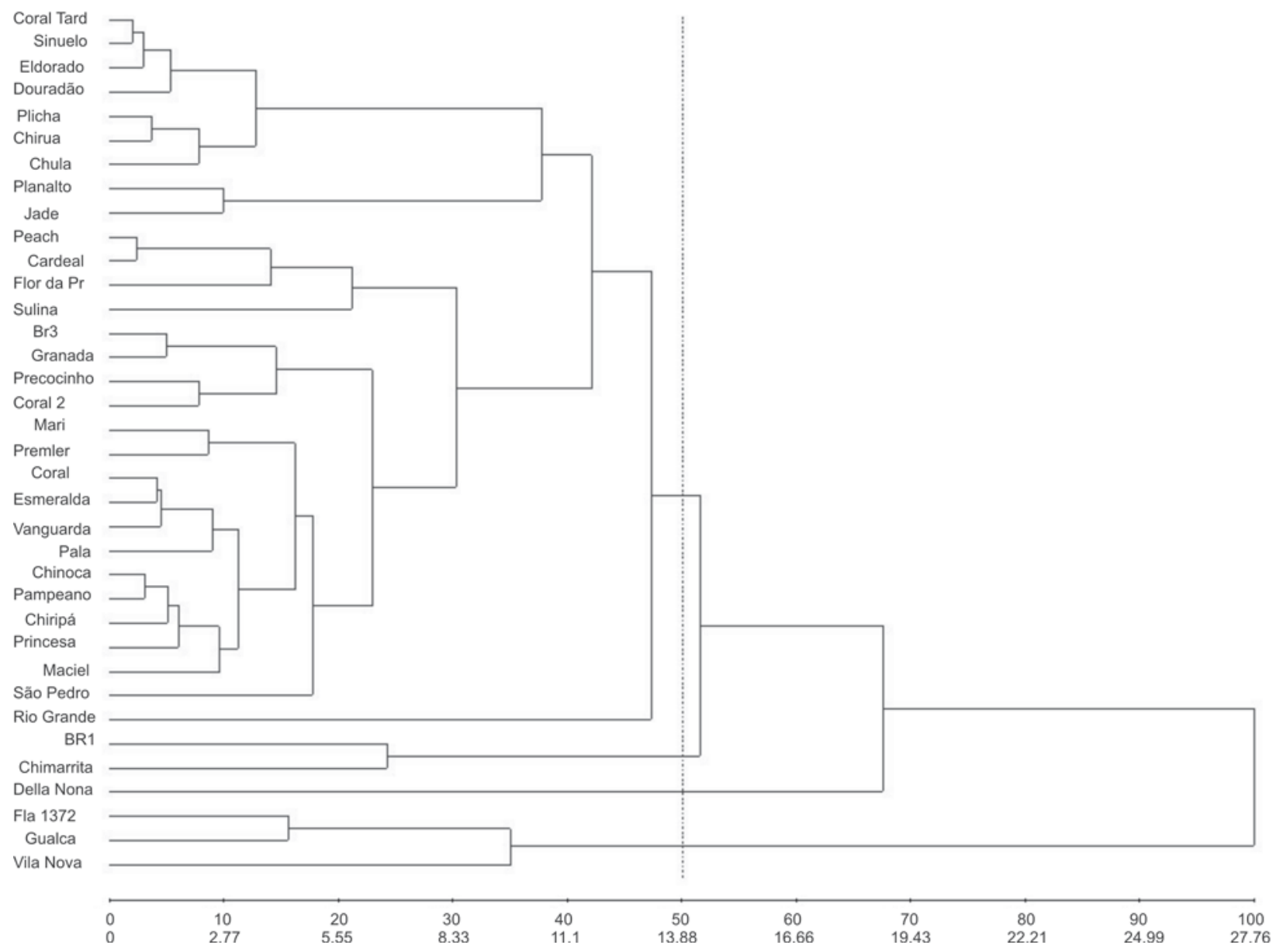

Figure 3. UPGMA dendrogram for 36 peach genotypes applied to Mahalanobis distance matrix based on six epidemiology traits related with leaf rust, in the cycles 2004/2005 and 2005/2006.

Rev. Ceres, Viçosa, v. 57, n.2, p. 185-193, mar/abr, 2010 
the others cultivars. 'Pilcha', 'Chirua' and 'Chula' are in the same group when are considered only $10 \%$ of divergence. This fact reinforces the results obtained by the analysis of canonical variables, in which the genotypes 'Vila nova' and 'Fla 1372' show great dissimilarity when compared with cvs. 'Pilcha', 'Chirua', and 'Chula', for leaf reactions.

We observed the existence of a susceptibility gradient to leaf rust among the peach cultivars. The use of less susceptible cultivars can reduce fungicide sprays in the field (Barbosa et al., 1994, Centellas-Quezada, 2000), reducing the production cost, the environmental contamination and the risk of the pathogen to acquire resistance to fungicides. However, cultivars less susceptible to peach leaf rust can not be adapted to the different weather conditions where the crop is grown, or not show good fruit quality. In this case, they could be crossed with other cultivars to obtain new cultivars more resistant to peach rust.

Centellas-Quezada (2000) observed that heritability of peach leaf rust resistance was high $(\mathrm{H}=0.64)$ in a population of Embrapa Clima Temperado genotypes, including "Cristal Taquari”, an immune cultivar. This fact suggests fast progress in breeding programs when "Cristal Taquari” is used as progenitor. Crosses using this cultivar transmitted the character of resistance efficiently, even in crosses with a susceptible parent such as "Chimarrita" (Chimarrita x Cristal Taquari). In our study the cv. Chula showed moderate susceptibility for severity (Table 2) and incidence (Table 4), however it was tolerant for defoliation (Table 3), contradicting Centellas-Quezada (2000) that used 'Chula' as susceptible progenitor in his studies of peach rust heritability. Probably when it was compared with 'Cristal Taquari', 'Chula' seemed to be susceptible.

\section{CONCLUSIONS}

It was not observed immunity for leaf rust in the studied peach cultivars;

There was difference in leaf rust intensity in each growing season;

Cultivars 'Chirua', 'Sulina', and 'Pampeano' are tolerant to leaf rust;

Cultivars 'Vila Nova', 'Fla 1372' and 'Chimarrita’ are highly susceptible to peach rust.

\section{REFERENCES}

Amorim L (1996) Principais doenças das fruteiras de clima temperado. In: Anais do $1^{\circ}$. Encontro Sul Mineiro de Fruticultura de Clima Temperado, Lavras. Anais. UFLA/EPAMIG/FAEMG. p.49-55.

Anderson HW (1956) Diseases of fruit crops. New York, McGraw Hill, 501p.
Barbosa W, Campo-Dall'Orto FA, Ojima M, Kalil, GPC, Lovate AA, Ribeiro IJA, MARTINS FP \& Nogueira EMC (1994) Incidência de ferrugem em folhas de pessegueiro e nectarineira do germoplasma IAC, Jundiaí, SP. Scientia Agrícola, 51: 90-93.

Bell AA (1981) Biochemical mechanisms of disease resistance. Annual Review of Plant Physiology, 32:21-81.

Bertrand PF (1995) Rust. In: Ogawa, JM, Zehr EL, Bird GW, Ritchie DF, Uriu K, Uyemoto JK (ed.) Compendium of stone fruit diseases. St. Paul, The American Phytopathological Society. p.23-24.

Bolkan HA, Ogawa JM, Michailides TJ \& Kable PF (1985) Physiological specialization in Tranzschelia discolor. Plant Disease, 69: 485-486.

Burnett HC (1968) Rust, Tranzschelia discolor (Fckl.) Trannz. \& Litv., on peach, Prunus persica (L.) Batsch. Florida, Florida Department of Agriculture, 2p. (Plant Pathology Circular $n^{\circ}$. 69).

Carvalho VL, Gonçalves-Gervásio RCR, Santa-Cecília LVC, Kato CM, Foureaux LV \& Campelo MG (2002) Alternativas de Controle da Ferrugem do Pessegueiro [Tranzschelia discolor (Fuckel), Tranzschel Litivinov]. Ciência e Agrotecnologia, 26: 227231.

Centellas-Quezada A (2000) Herança da época de floração e da resistência a ferrugem da folha em pessegueiro. Tese de Doutorado, Universidade Federal de Pelotas, Pelotas, 59p.

Citadin I, Bertuol O, Bassani MH, Sousa RN de, Pinotti LCA \& Soletti T (2005) Controle da Ferrugem da Folha do Pessegueiro Mediante Pulverizações com Diferentes Fungicidas. Revista Brasileira de Fruticultura, 27:317-319.

Cruz CD (2006) Programa GENES: análise multivariada e simulação. Viçosa, Editora da UFV. 175p.

Cruz CD (2001) Programa Genes: versão Windows; aplicativo computacional em genética e estatística. Viçosa, Editora da UFV. 648p.

Garrido LR \& Sônego OR (2005) Doenças do pessegueiro na Região da Serra Gaúcha. Bento Gonçalves, Embrapa Uva e Vinho. 11p. (Circular Técnica 61).

Goldsworthy MC \& Smith RE (1931) Studies on rust of cling peaches in California. Phytopathology, 21:133-168.

Johnson RA \& Wichern DW (1998) Applied multivariate statistical analysis. Upper Saddle River, Prentice Hall. 816p.

Martins MC \& Amorim L (2000) Caracterização morfológica e especialização patogênica de Tranzschelia discolor em diferentes espécies de Prunus. Fitopatologia Brasileira, 25: 79-83.

Martins MC (1994) Quantificação dos parâmetros monocíclicos e controle químico da ferrugem do pessegueiro. Dissertação de Mestrado, Escola Superior de Agricultura "Luiz de Queiroz”, Piracicaba, 68p.

Pascholati SF \& Leite B (1997) Hospedeiro: mecanismos de resistência. In: Bergamin Filho A, Kimati H \& Amorin L (eds.) Manual de fitopatologia: princípios e conceitos. São Paulo, Editora Ceres. p.417-454.

Scott AJ \& Knott MA (1974) Cluster analysis methods for grouping means in analysis of variance. Biometris, 30:507-512.

Singh D (1981) The relative importance of characters affecting genetic divergence. The Indian Journal of Genetics \& plant breeding, 41: 237-245.

Soto-Estrada J \& Adaskaveg JE (2004) Temporal and Quantitative Analyses of Stem Lesion Development and Foliar Disease Progression of Peach Rust in California. Phytopathology, 94: 52-60. 